\title{
数値予報モデルによる地上風の予測 \\ Surface wind forecasts with numerical weather prediction models
}

\author{
瀬 上 哲 秀* \\ Akihide SEGAMI
}

\section{SUMMARY}

This describes the method of prediction of surface wind fields by use of numerical models at Japan Meteorological Agency (JMA). The concept and the system of the numerical weather prediction are shown first, because the numerical weather prediction is now essential to weather and wind field predictions. Numerical models at JMA are also summarized with the emphasis of surface friction schemes.

Forecasts of surface winds by the numerical prediction model (JSM) are fairly accurate except for regions of complex terrain. To improve forecasts over such regions, one-level surface wind model is being developed. The model requires a modest computer resources. It will be operated at local forecast centers using their work-stations.

\section{1.はじめに}

花鳥諷詠を重んじる国民性のゆえか, 変化に飛んだ 風土のためか, はたまた, 当たり障りのない話題のお 陰か, 人々はよく天気のことをロにする。そしてその 時には, 当たり外れのある天気予報のことも必ず話題 にのほる。お堅いのが常のお役所仕事にあって, 天気 予報ほど多くの人に親しまれているものはない様に思 う。ただし，茶化されたりお叱りを頂くことはあって も, 当ったといって決して褒められることのない, 損 な商売でもある。しかしながら，このように身近な天 気予報がどの㥞にして作られているのか, 知っている 人は少ないのではないかと思われる。気象庁が日々発 表する天気予報の基になる資料としては, 気象衛星ひ
まわりやアメダスが良く知られている。しかし実際に は, 「数値予報」という大型計算機を使った予測が, 天気予報にとって最も重要になっており，極く短時間 の予報を除き, 明日, あさっての予報や週間予報の中 心をなしている。ところが, この数值予報という言葉 すら, 知っている人がほとんどいないのが現状であろ j。

ここでのテーマは風の予測であるが, 風は気圧差が 原因で起こるので，風の予測をしょうと思えば気圧場 (高気圧や低気圧)の予想をうまくしなければならな い。気压場の予想は天気予報の基本である。つまり, 天気予報を抜きにして風の予測法だけを取り出して述 べることは出来ない。そして, 天気予報の話しをしょ

* 気象庁数値予報課

Numerical Prediction Division, Japan Meteorological Agency

(平成 2 年 4 月 7 日 受理) 
うとすれば, どうしても数值予報の話しを避けて通る

ことは出来ない。そこで, 先ず数值予報とは何かとい うところから入っていくことにする。

\section{2. 数値予報の原理}

大気の状態（気温，風，気圧，水蒸気）とその時間 変化は, 物理法則に従って, 幾つかの方程式で記述さ れる。観測によってある時刻の大気の 3 次元的な状態 が分かれば，これらの方程式を初期值問題として解い て, 任意の時刻の状態を決定論的に決めることが出来 る。ただし，方程式は非線形偏微分方程式であるので， 解析解の重ね合わせや単純外挿では解けない。大型計 算機を使って, 数值的に解くしかない。このようにし て将来の大気の状態を予測することを数値予報と呼ん でいる。

支配方程式は,

(1) 運動方程式 (Navie-Stokesの方程式)

風速（東西成分，南北成分）の時間変化を規 定する

(2) 熱力学の式 (エネルギー保存の式)

気温の時間変化を規定する

(3) 連続の式（質量保存の式）

(4) 水蒸気保存の式

からなっている。この中では, 大気の 3 次元的な運動 だけでなく, 地表面付近での摩擦効果, 太陽の日射や 放射冷却, あるいは雲が出来て雨が降るなどのプロセ スも計算されている。

予報変数を $\mathrm{A}$ とすると, これらの方程式は簡単に

$$
\frac{\partial u}{\partial t}=F(t)
$$

の形に書ける。これを差分の形に直すと, 初期値 $(\mathrm{t}=0)$ から $\Delta \mathrm{t}$ 時間後の $\mathrm{A}$ の值は次のように得られる。

$$
u(\Delta t)=u(0)+F(0) * \Delta t
$$

$\Delta \mathrm{t}$ 時間後の值が求まれば, 同じ方法でさらに $\Delta \mathrm{t}$ 時 間後....と繰返し行なうことで，原理的に任意の時刻 の值が得られる。ここで, $\Delta \mathrm{t}$ は数值予報モデルの分 解能や風速に依存し, 風速が早いほど, また分解能が 細かいほど短い時間間隔を取る必要がある(時間積分 の安定条件：CFLコンディション)。後で述べる全 球モデルでは15分, 日本域モデルでは 3 分程度である。

なお，(1）式のFには空間微分の項も含まれる。こ れには, 差分を用いたり直交関数系で展開したりして
表現している。数值予報についてのさらに詳しい説明 は, 増田(1981)を参照されたい。

\section{3. 気象庁の数値予報システム}

数值予報のシステムは,Fig. 1に示すように,観測デ 一夕の収集, 解読, 解析, 予報, 応用処理からなって いる。

先ず，観測データの収集を行なう。（もちろん，観 測をする必要があるが)。世界中で観測された気象デ ータが, オンラインで気象庁本庁に集められる。コー ド化された電報形式で送られるので，それを気温など の物理量に解読する。数值予報で使われるデー夕には, 地上観測, 高層のゾンデ観測, 航空機や気象衛星で観 測されたデータなどがある。これらの観測デー夕は， 観測手段により精度がまちまちであり，かつ，不規則 に分布している。数値予報を行なうには, 規則正しい 格子点上で值が分布していることが望ましい。観測デ 一夕の精度を考虑しながら, 格子点上の值に内挿する ことを客観解析と呼んでいる。この客観解析された場 が, 数值予報の初期値となる。予報された結果はいろ いろ応用処理され, 画像データ, G P V (格子点デー 夕）として，全国の気象官署に送られる。これを使い， ひまわりやアメダス, レーダーのデータを考虑しなが ら，天気予報が出されるのである。

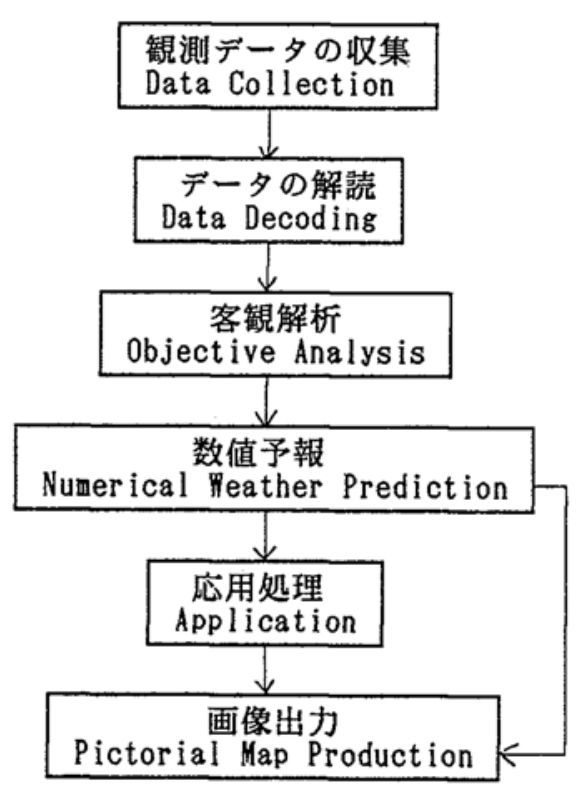

Fig. 1 数値予報のシステム

Numerical weather prediction system. 


\section{4. 数値予報モデルの種類と予報例}

気象庁では, Table.1のように4つの数值予報モデルが 現業的に運用されている。それぞれ，目的や子報領域， 分解能が異なっている。なぜ,このようにいろんなモ デルが必要なのか。たとえば，1つの数値予報モデル で全球を覆うとする。よりきめ細かい予報をするため には，モデルの空間分解能を小さくする必要がある。 もし，分解能を 3 次元的に半分にしたとすると，格子 点数は $2^{3}=8$ 倍になる。時間積分の安定条件により, $\Delta \mathrm{t}$ も半分にする必要があるので, 結局, 計算時間は
16倍かかることになる。したがって，全球を覆う予報 モデルに対しては分解能を粗くし，分解能を細かくし 集中豪雨などを予測しようとすれば(たとえばJSM)， 領域を狭くしなければならない。このため，目的に応 じて予報領域や分解能が異なったモデルが必要になる。 なお，なぜ全球を覆うモデルが必要化といえば， 1 週 間先の天気予報をする場合，地球の裹側，つまりヨー ロッパ付近の低気圧や高気圧が日本の天候に影響を及 ぼしうるからである。

Fig. 2に日本域モデル（J S M）の予報領域と地形を

Table 1 気象庁ルーチンモデルの概要

Outline of operational numerical weather prediction models in JMA

\begin{tabular}{|c|c|c|c|c|}
\hline & $\begin{array}{c}\text { 全球モت゙ル } \\
\text { Global Spectral Model } \\
\text { (GSM) }\end{array}$ & $\begin{array}{c}\text { アシアモアル } \\
\text { Asia Spectral Hodel } \\
\text { (ASM) }\end{array}$ & $\begin{array}{c}\text { 日本㽣モデN } \\
\text { Japan Spectral Model } \\
\text { (J S M) }\end{array}$ & $\begin{array}{l}\text { 台囷モデル } \\
\text { Typhoon Model } \\
\text { (TYM) }\end{array}$ \\
\hline 目的 & 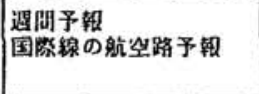 & 明日、あむっての & 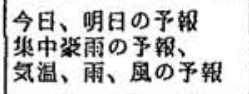 & 台成の進路予想 \\
\hline 予赤領域 & 全球 & 東アシア & 日本付近 & 台国中心付近 \\
\hline 水平分解能 & $110 \mathrm{~km}$ & 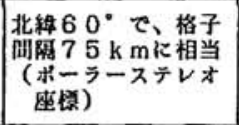 & 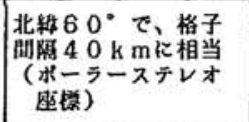 & 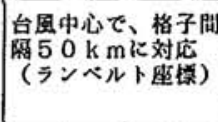 \\
\hline 纷面レペル & 21 周 & 16 屏 & 18圈 & 8 首 \\
\hline $\begin{array}{l}\text { 予派時閌と } \\
\text { 回数 }\end{array}$ & $\begin{array}{l}3 \text { 日予報 (1 } 1 \text { 日 } 1 \text { 回) } \\
8 \text { 日予報 } 1 \text { 日 } 1 \text { 回) } \\
15 \text { 日予報 }(\text { 月 } 3 \text { 回 })\end{array}$ & $\begin{array}{l}\text { 2日予報 } \\
\text { (1日2回) }\end{array}$ & $\begin{array}{l}\text { 1日予報 } \\
\text { (1日2回) }\end{array}$ & $\begin{array}{l}60 \text { 時問予報 } \\
\text { (必要に店じて) }\end{array}$ \\
\hline
\end{tabular}

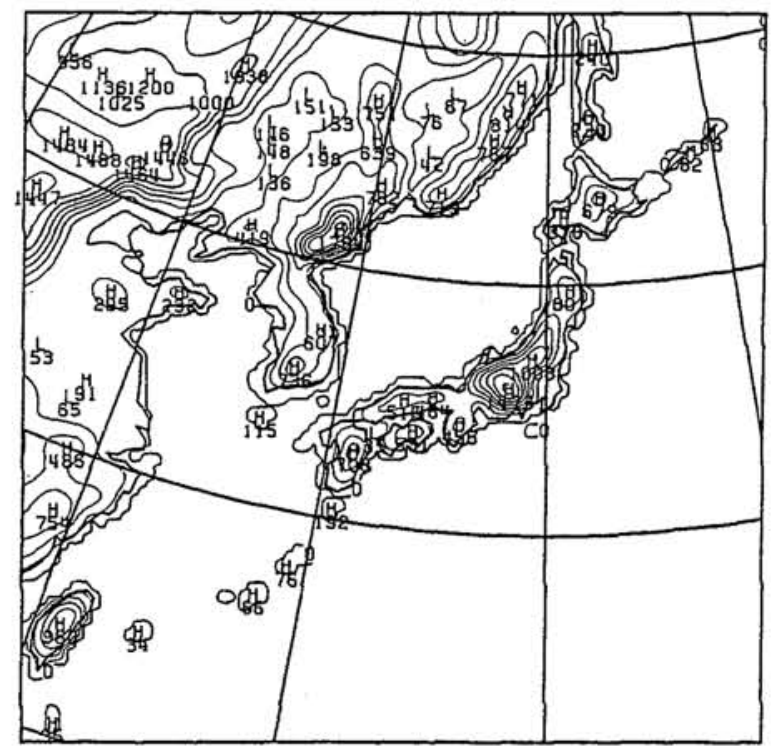

Fig. 2 J S Mの予報領域と地形

Forecast domain and topography of JSM. 

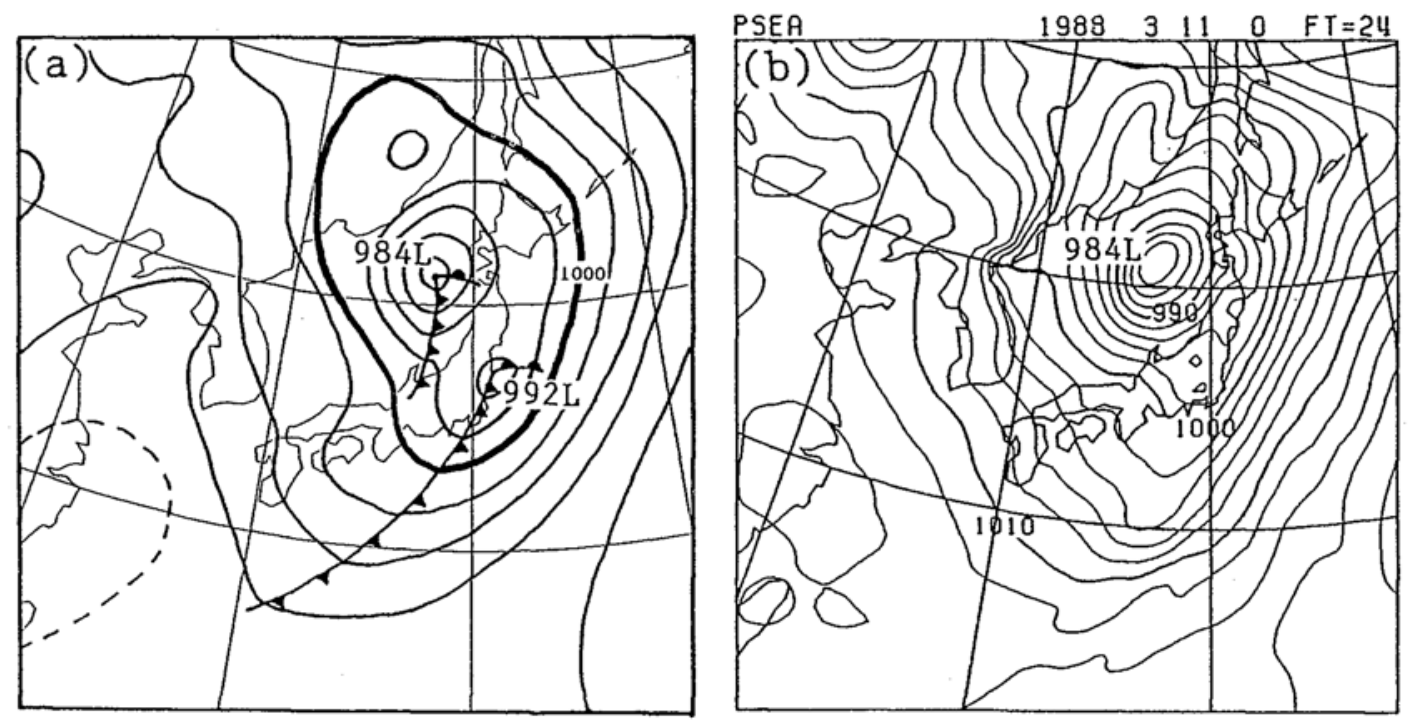

Fig. 3 J S Mによる地上気圧の24時間予報 (b)とその時の実況 (a). 初期値は1988年 3 月11日00GMT. 24-hour forecast of surface pressure by JSM (b) and its verification (a). Initial time is 00GMT 11 March 1988.

示す。また, Fig.3に J S Mによる 24 時間予報の例を 示す。中国大陸にあった低気圧が24時間で $24 \mathrm{mb}$ 発達し 北海道の西に移動した。この低気圧の急激な発達と位 置が共に，非常に良く予報されていることが分かる。 関東付近に別の低気圧が発生することも予想されてい る。この例だけでなく, 最近の数值予報では, 3 日先 程度の気圧場はかなり良く予報されるようになってい る。

\section{5. 大気境界層内の風予測}

今まで述べてきたように，数值予報モデルでは風は 気温や気圧と同じように予報変数となっており, 任意 の時刻の 3 次元的状態を予測することが出来る。この 結果は, 通常の天気予報はもちろんのこと, 国内線, 国際線の航空路の予想にも広く使われている。ただし， 一般の人にとって重要なのは上空の風ではなく, 地上 に極く近い所の風向風速である。地上付近地面によ る摩擦が強くなるため, 特別の取り扱いをする必要が ある。流体力学では, 固体壁近くの摩擦の卓越する領 域を境界層と呼んでいるが, 我々も地上 $1500 \mathrm{~m}$ 位まで の層を大気境界層と呼んでいる。そして, 特に地上 50 $\mathrm{m}$ 位までを接地境界層という。

我々のモデルでは, 大気境界層を精度良く予報する ため, 大気の下層にたくさんのレベルをとっている。 その上, 境界層付近で発生する乱流による摩擦の効果
も取入れている。以下にこの点を説明する。

一般に大気などの流体では, 分子粘性だけでなく, 非線形相互作用の働きで乱流(渦)によっても摩擦（渦 粘性とよぶ）が生じる。そして，この渦粘性が大気境 界層では重要となる。

流れの場を平均流とそこからのずれ（乱流量）に分 けたとする。つまり，

$$
u_{1}=\overline{u_{1}}+u_{i}{ }^{\prime}
$$

ここで，(') は平均量，('）はそれからのずれ（乱 流量）を意味する。数值予報モデルでは, 格子点の值 を平均量とし, それょり小さなスケールの現象を乱流 として扱っている。この時, 平均場に対する方程式に は，渦粘性による項が付加される。(Rotta（1975）の $\mathrm{p} 45$ 参照)。この時, たとえば(1)式は次のようになる。

$$
\frac{\partial \overline{u_{i}}}{\partial t}=F-\frac{\partial \overline{u_{i} \cdot u_{j}}}{\partial x_{j}}
$$

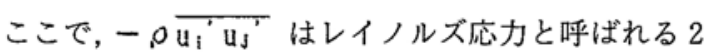
次の統計量 (モーメント) である。結局, この量を求 めれば良いのだが, これを求める方程式を作れば 3 次 の統計量が現われ, さらに 3 次を求める方程式には 4 次が現れる....というように, 何処までいっても方程 式は閉じない。なんらかの別の仮定を用いて $\mathrm{n}+1$ 次 のモーメントを $\mathrm{n}$ 次以下のモーメントで表わし, 方程 式系を閉じさせる必要がある。これを完結問題(Closure 
problem ) と言い，その時の仮定を $\mathrm{n}$ 次の完結仮定 (Closure assumption)と言う。我々の数值モデルでは, 次のような極く簡単な 1 次の完結仮定を用いている。

$$
-\overline{u^{\prime} w^{\prime}}=K_{M} \frac{\partial u}{\partial z}
$$

ここで, $\mathrm{K}_{\mathrm{M}}$ は渦拡散係数とよばれ, 高さによって変 化する。そして，(3) 式は $\mathrm{u}$ (風の $\mathrm{x}$ 成分) に対して 次のような方程式になる。

$$
\frac{\partial \bar{u}}{\partial \mathrm{t}}=\mathrm{F}-\frac{\partial \overline{\mathrm{u}^{\prime} \mathrm{w}^{\prime}}}{\partial \mathrm{z}}
$$

なお, 大気境界層では水平に比べて鉛直方向の変化が 遥かに大きいので, 鉛直微分のみ考虑している。

さて, 大気の成層状態が中立の時（大気の気温隇率 が $1{ }^{\circ} \mathrm{C} / 100 \mathrm{~m}$ の状態。地上付近では極く普通の状態で ある），接地境界層の風速の鉛直分布は, Fig.4のよう な対数則に従うことが観測から良く知られている。こ の図で, 風速がゼロになる所まで外挿した時の高度 $z_{0}$ を粗度と言う。粗度は地表面の凹凸度を表わすパラメ ーターで, この值が大きいほど摩擦が大きくなる。 対数則は,

$$
u \propto \log \left(\frac{z}{z_{0}}\right)
$$

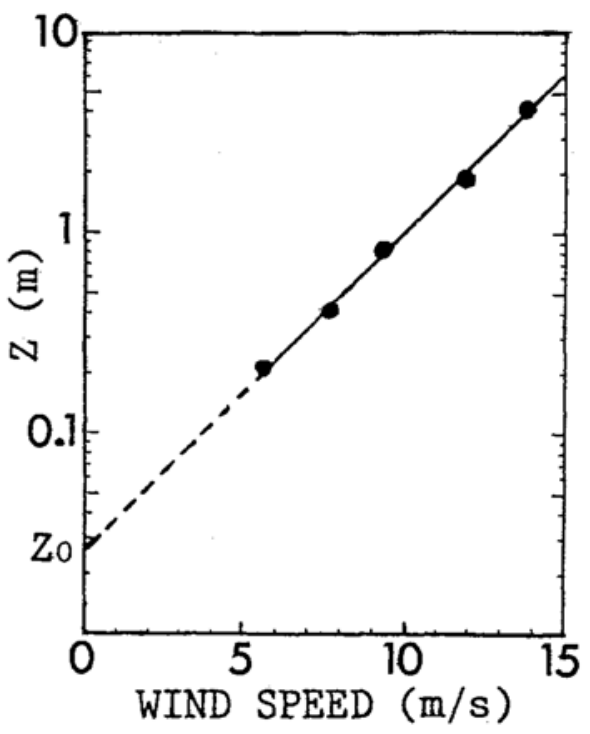

Fig. 4 地表面付近での風速

Wind speed near ground surface.
あるいは,

$$
\frac{\partial u}{\partial z} \propto \frac{1}{z}
$$

という形に書ける。一方, 接地層では, 摩擦項は他の 項に比べて非常に大きいので，(5) 式は

$$
\frac{\partial \overline{u^{\prime}}}{\partial z}=0
$$

となる。(この式は $\overline{u^{*} w^{\prime}}=$ 定数,つまり乱流による 運動量の鉛直輸送が高さによらず一定であることを意 味する)。これを(4)，(6')式と比較すると，

$$
\mathrm{K}_{\mathrm{M}} \propto \mathrm{z} ; \mathrm{K}_{\mathrm{M}}=\kappa \mathrm{U}_{* \mathrm{z}}
$$

として求まる。ここで， $\kappa(=0.4)$ はカルマン定数で ある。また, U*は摩擦速度とよばれ, 速度の次元を もつ。大気の成層が中立以外の時は, 対数則から若干 ずれて, (7) 式の渦拡散係数は

$$
K_{M}=\kappa u_{*} 2 / \phi_{M}
$$

となる。 $\phi_{M}$ は普遍関数と呼ばれ, 大気の安定度に依 存する。我々は $\phi_{M}$ としてBusinger(1971)が観測から 求めた実験式を用いている (竹内・近藤, 1981参照)。 また, 粗度としては植生から求めた適当な気候値を用 いている。

以上は接地境界層の渦拡散係数であるが, その上の 上部境界層では, Mellor \& Yamada (1974) のレベル 2 のクロージャー・モデルを用いて渦拡散係数を求めて いる。

\section{J SMによる地上風の予測精度}

地上付近の風は, 細かな地形や建物の影響を強く受 けている。数值モデルで予測しようとするのは, もち ろんこの様な局所的な風ではない。例えばJ SMの分 解能は $40 \mathrm{~km}$ (東京付近で $34 \mathrm{~km}$ 程度) であり, せいぜい 波長200kmぐらいの波を表現できるに過ぎない。一方 アメダスは, 風に対しては $21 \mathrm{~km}$ の格子に 1 個の割合で 分布しているが（雨は $17 \mathrm{~km} に 1$ 個），付近の建物の影 響などで，必ずしも空間代表性の良くない地点もある。 したがって，この両者を直接比較するには問題もある が, 他に観測データもないので，ここではアメダスを 使って J SMの風予想の精度を検証した結果を示すこ とにする（萬納寺，1989）。

J SMの格子点值を, その格子点を中心とする $40 \mathrm{~km}$ 


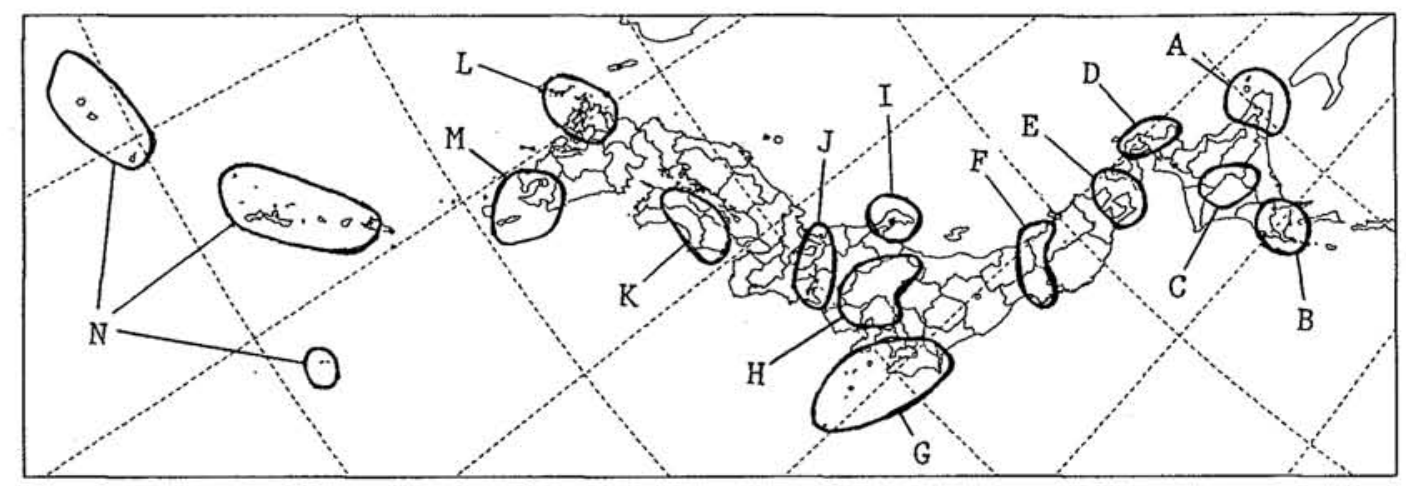

Fig. 5 表 2 で示した地域

Regions specified in Table 2.

Table 2 風向の誤差が $\pm 22.5^{\circ}$ 以内である割合 Percentage of wind direction error within $22.5 \mathrm{deg}$.

* 40kmの枠内にあるアメダス地点の観測の平均值と比 較する。平均は, 風速については算術平均（スカラー 平均）し，風向についてはべクトル平均した風の風向 を用いる。また，風向については，モデルで $2 \mathrm{~m} / \mathrm{sec}$ 以上の場合のみ対象とした。

調査期間は, 1988年 4 月から89年 3 月までの 1 年間 である。J S Mの12時間予報結果のみを示す。24時間 予報でも精度はほとんど変らない。

\section{1 風向の予測精度}

風向の予測には，地域特性がよく表れる。Fig. 5に示 すような特徵的な14の地域を選び，その風向の一致率 (風向の誤差が $\pm 22.5^{\circ}$ 以内である割合)をTable. 2 に示す。これらの地域は,比較的予報精度の良い地域 と,そうでない所に分けられる。予報精度の良い地域は， 基本的に細かな地形の影響を受けていない所である。 それをさらに，

(1) 地形の影響をほとんど受けない地域（A，B， $\mathrm{G}, \mathrm{N}$ )

(2) モデルで表現できる程度の地形で卓越風向が決 まる地域 ( E , F, I , J , M )

(3) 卓越風向に対して障害物が無い地域 (D, L) の 3 つに分けることが出来る。また，予報の悪い地域 は

(4) 内陸の山岳地域 $(\mathrm{C}, \mathrm{H}, \mathrm{K})$

である。

(1)は釧路・根室 (B) や南西諸島 (N) など, 地形 が平坦で気圧傾度による風が素直に吹く所である。参 考のため, 釧路・根室のFig. 6に89年1月の風向の散布 図を示した。 $0^{\circ}$ は北風, $90^{\circ}$ は東風， $-90^{\circ}$ は西風

\begin{tabular}{|c|c|c|c|c|c|}
\hline 距号 & 地填名 & 4月 & 7月 & 10月 & 1月 \\
\hline A & 宗谷・留萌北部 & 50 & 44 & 56 & 53 \\
\hline B & 鍃路・根室 & 50 & 51 & 56 & 52 \\
\hline c & 北海道の山地 & 26 & 12 & 30 & 23 \\
\hline D & 敖丹一江差 & 34 & 36 & 48 & 48 \\
\hline $\mathrm{E}$ & 津艁海蛱 & 48 & 57 & 51 & 57 \\
\hline $\mathrm{F}$ & 仙台一酒田・烀田 & 44 & 61 & 43 & 44 \\
\hline G & 関東平野南部 • 伊豆 & 54 & 53 & 41 & 44 \\
\hline $\mathrm{H}$ & 中部山地 & 18 & 18 & 19 & 22 \\
\hline I & 能登半島 & 54 & 48 & 44 & 47 \\
\hline $\mathrm{J}$ & 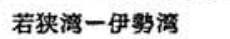 & 50 & 47 & 44 & 43 \\
\hline $\mathrm{K}$ & 四国の山地 & 19 & 7 & 21 & 17 \\
\hline L & 佐貿・長䗁 & 54 & 50 & 44 & 43 \\
\hline M & 毞児島 & 48 & 48 & 46 & 47 \\
\hline $\mathrm{N}$ & 南西锗島 & 58 & 60 & 72 & 68 \\
\hline
\end{tabular}

である。ななめの細線は, 誤差が $\pm 22.5^{\circ}$ と $\pm 45^{\circ}$ を意味する。ほとんどが $\pm 45^{\circ}$ 以内に入り，予報がか なり良いことが分かる。

(2)については，地域 F（仙台一酒田・秋田）を例に とって説明する。Fig. 7は，この地域の 1 月と 7 月の散 布図である。冬は北西風, 夏は南東風が観測で卓越す るが，J SMでもそれを良く予報している。J SMモ デルで表現される程度の地形 (Fig. 2の地形にあるよう な仙台から酒田・秋田にかけての大きな谷筋）で，実 際の卓越風が決まっているためであろう。

(3)は，ある方向の風に対して精度の良い地域である。 


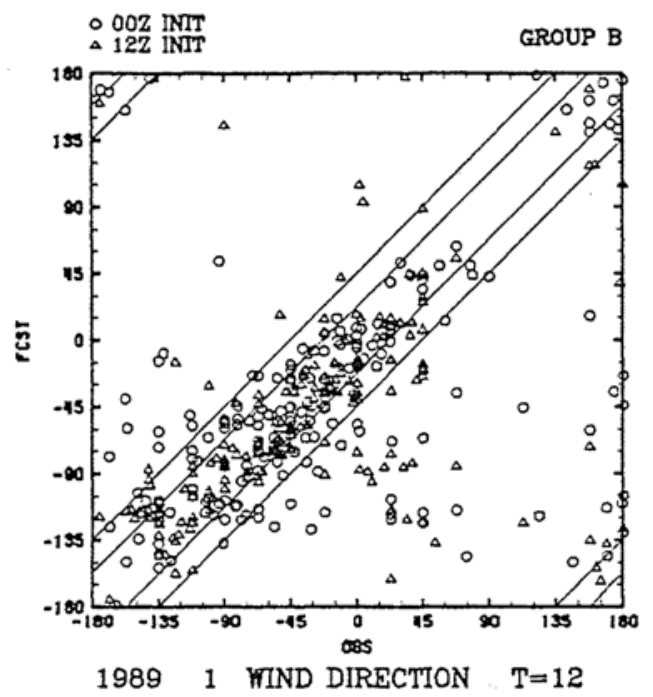

Fig. 6 地域 Bの1989年 1月の風向の散布図 横軸は観測，たて軸は12時間予報を意味する Scattered diagram of wind direction for January 1989 at Region B.

Abscissa indicates observation and ordinate shows 12-hour forecasts by JSM.

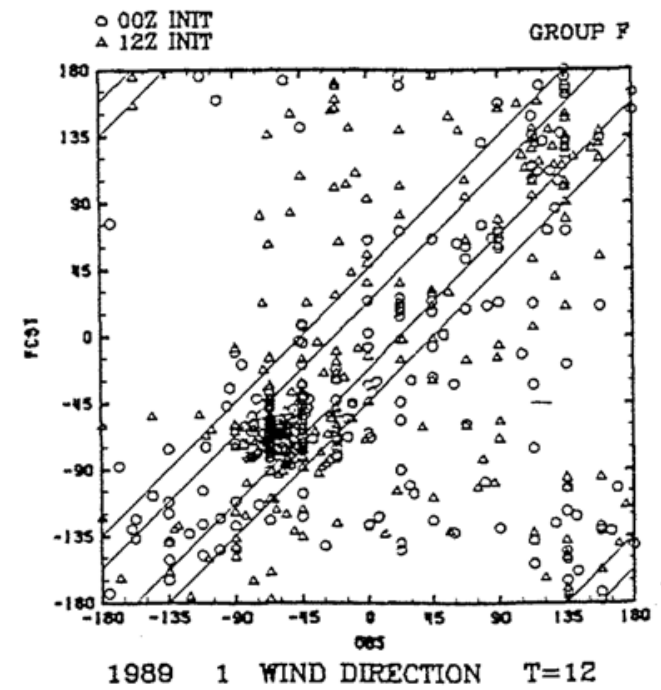

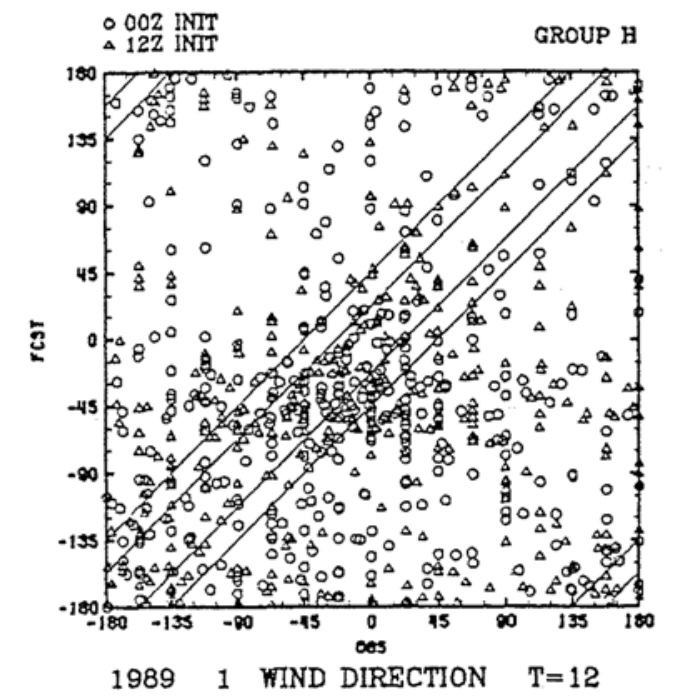

Fig. 8 地域Hの89年 1 月の風向の散布図 Same as Fig. 6 except for Region H.

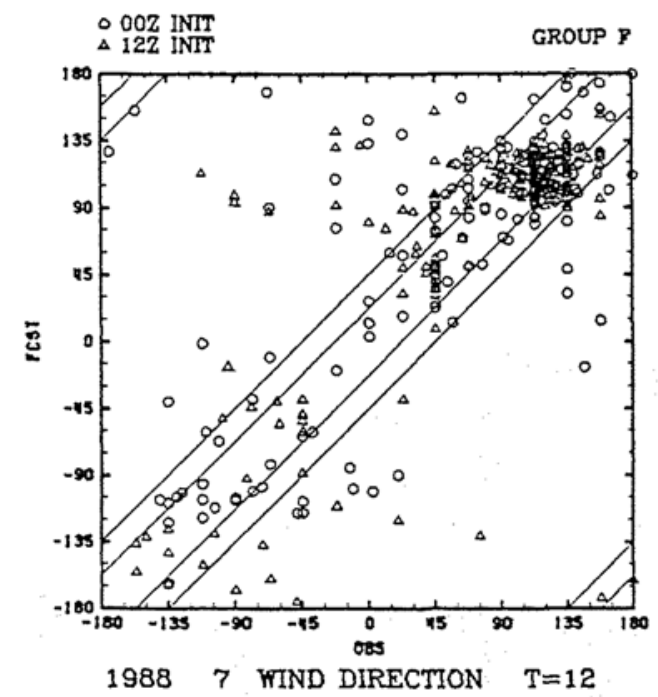

Fig. 7 地域 $\mathrm{F}$ の風向の散布図。左図は89年 1 月，右図は88年 7 月。

Same as Fig. 6 except for Region F. Left panel:January 1989. Right panel:July 1988.

例えば地域D (䅡丹, 江差)では, Table.2に示すように, 10 月・1 月に西北西の風が卓越する時にモデルの予報 精度が良く，他の季節では良くない。

(4)の予報精度の良くない地域は, モデルの地形より 小さい, 複雑な地形の影響を強く受けている所である。 Fig. 8に中部山岳の散布图を示すが,非常に精度は悪い。
以上の結果は，基本的に J S Mの気圧場の予想が良 いことを意味している。そして，障害物がない地域, あるいは，J S Mで表される程度の地形に強制される 地域では, 風向の予報精度が良く, 山間部などの複雑 な地形の所では精度が悪いということである。 


\section{2 風速の予想精度}

風速の予想精度は, 風向ほどには良くない。例えば 地域 B (釧路・根室) と H (中部山岳) の一月の風速 の散布図をFig. 9に示す。Hが悪いのは仕方ないとして， $\mathrm{B}$ も風向の分布に比べてばらつきがかなり大きくなっ
ている。そして, モデルの風は観測に比べて弱めに予 想されている。これは，第 3 節で述べたモデルの粗度 が大きすぎ，摩擦が効きすぎているためであろう。し かし明らかな相関が有るので，なんらかの補正をする ことで予報として使うことが可能である。
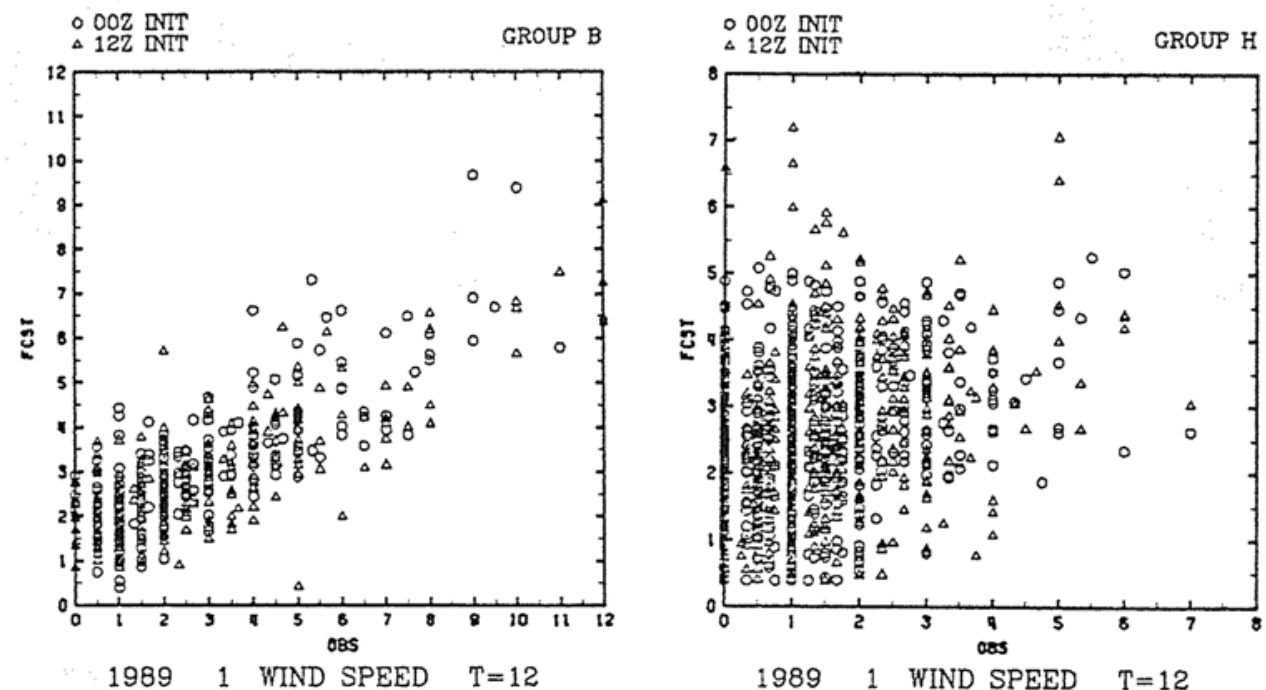

Fig. 9 地域B (左図) と地域 H (右図) の1989年 1 月の風速の散布図

Scattered diagram of wind speed for January 1989 at Region B (left panel) and Region $\mathrm{H}$ (right panel)
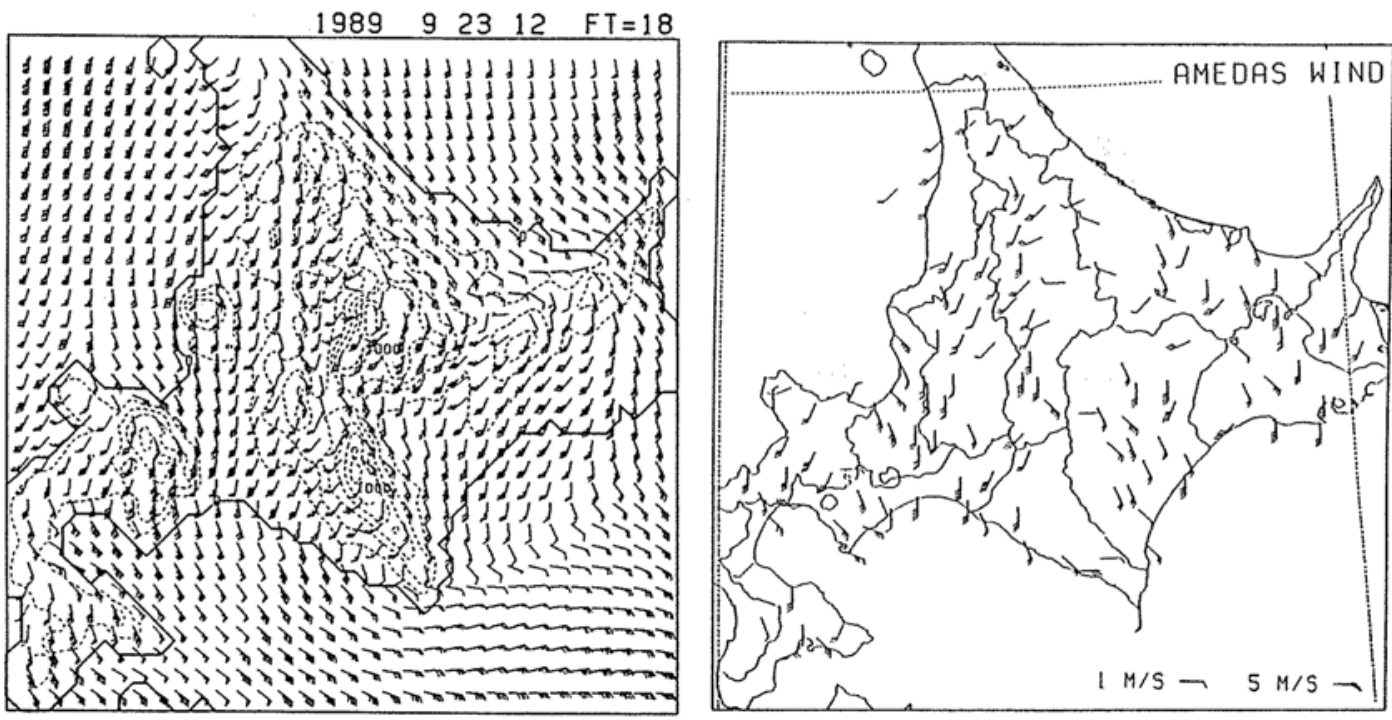

Fig. 10 風一層モデルの18時間予報の風の場とそれに対応する1989年 9 月24日15時のアメダスの実況図 18-hour forecast of wind fields by One-level surface wind model and corresponding observation by AMeDAS at 15LST on 24th Sep. 1989. 


\section{7. 将来の展望}

J S M は山岳部などの複雑地形上での風の予測は良 くない。これを解決する方法として，J SMをさらに 高分解能化することが考えられる。実際, 分解能を10 kmにしたテストでは, 非常に結果か改善されている。 このことは，J S Mにうまく複雑地形の影響を取込め ば，地上の予報が大きく改善される事を示唆している。 しかし，10kmのモデルで日本全国を覆うとすれば，計 算機資源が100 倍以上かかる事になり, 当面は現業的 に利用することは不可能である。そこで，地形の影響 を簡単化して取入れ, 地上の風だけを予想する「風一 層モデル」を開発しテスト中である。 Mass \& Dempsey （1985）のモデルを基にし，より現実的な改良（側面境 界の変化, 熱の取入れ方など）を行なったモデルであ る。計算時間があまりかからず, 高分解能化が出来る のが利点である。このモデルの予報例をFig. 10に示す。 海風が南から石狩平野に入り, そして石狩湾を抜けて いる。それが回り込んで天塩平野でまた海風となって 入っていく。また, 十勝平野での海風, オホーツク海 沿岸での海岸線に沿う風など, モデルの予報は良く実 況と一致している。

このモデルを, 地方の気象官署のワークステーショ ンで走らせることを計画中である。

\section{参考文献}

竹内清秀 ·近藤純正 (1981)：地球に近い大気, 東京大 学出版会。

萬納寺信崇 : 地上風の検証, 数値予報解説資料 (22), 気象庁, pp33-44 (1989)。

增田善信 : 数值予報一その理論と実際一, 東京堂出版, 278pp (1981)。

Rotta, von J. C. : 乱流, 岩波書店, $277 \mathrm{pp}$ (1975). Mass, C. F. and D. P. Dempsey : A one-level, mesoscale model for diagnosing surface winds in mountainous and coastal regions,

Mon. Wea. Rev., Vol.113, pp1211-1227 (1985).

Mellor, G. L. and T. Yamada : A hierarchy of turbulence closure models of planetary boundary layers, J. Atm. Sci., Vol. 31, pp1791-1806 (1974).

Segami, A., K. Kurihara, H. Nakamura, M. Ueno, I. Takano and Y. Tatsumi: Operational mesoscale weather prediction with Japan Spectral Model, J. Met. Soc. Japan, Vol.67, pp907-924 (1989).

\section{質疑応答}

とりまとめ 花房 龍男*

質問 多くのモデル方程式を使われているようですが, どの程度確立されたものなのでしょうか。数值計算の 方法についてはいかがですか。（田村 哲郎）

回答 数値予報で行なっている計算を, 力学過程と物 理過程の 2 つに分けて考えることができます。力学過 程というのは大気の運動に関係する項で, 気圧勾配に よって風が吹いたり, また, 風によって物理量が流さ れたりするのを計算する部分です。一方, 物理過程で は, 放射（日射による地面の加熱や放射冷却，またオ ゾン層での紫外線の吸収など）対流（雲ができ, 雨が 降ること）そして乱流過程（大気境界層内での摩擦力 や，地表面からの蒸発など）などを計算しています。 力学過程の方程式系に関しては完全に確立されていま
す。座標系の取りかたで，表現の形式が若干異なる程 度です。数值計算の手法も概ね固まっていると言って 良いでしょう。（いかに速く（もちろん正確に）計算 するかという点で改良の余地はありますが)。現在の 気象庁のモデルでは, 空間に関し, 鉛直は格子点, 水 平はスペクトル法で場を表現しています。全球モデル ではルジャンドル関数,領域モデル(ASM, JSM, TYM) では 2 重フーリエ関数を使っています。時間積分は, 方程式系を位相速度の遅い気象学的に意味のある波と 位相速度の速い重力波に分け，前者についてはリープ フロッグ, 後者はインプリシット化して $\Delta \mathrm{t}$ を長くとり， 計算時間の短縮を計っています。

一方, 物理過程に関しては, 自然界で起こっている

\section{*気象庁 観測部}


現象に少しでも近づけるという大前提でモデルの精密 化を計っていますが, 計算資源の問題や, そもそも自 然現象がどの様なメカニズムで起こっているかが解明 されていないことなどが原因でまだまだ改良の余地が ありそうです。特に対流現象に関しては。

質問 台風のシミュレーションについて, 全球でなく 部分的な領域を解いているとしたら, 周辺の境界条件 はどの様に設定しているのですか。（田村 哲郎）

回答 全球を覆わない領域モデル（ASM，JSM，台風 モデル）では，側面境界の值をより大きなモデルの予 報からもらっています。つまり,ASMと台風モデルでは 全球モデルから6時間ごとに,JSMではASMから3時間ご とに境界值をもらい，その間の時間は線形に内㨉して 使っています。(2重フーリエを使ってどうして境界值を 取り込めるかはTatsumi (1986)気象集誌64巻を参照し て下さい)。現在のところ, 外のモデルと内のモデル の境界での槃ぎには問題はなく, 空間分解能の粗い外 のモデルで表現できる高気圧, 低気圧などはモデルの 側面境界を通してスムーズに出入りすることが可能で す。しかし，小さな台風などは全球モデルでは表現で きないので, 台風モデルでは, 初期にモデルの中央付 近に台風を置き，境界の影響がなるべくでないように 配慮しています。この場合, 全球モデルは進路予報に 重要な台風の周りの場を与えていると考えれば良いで しょう。

質問 風に対する地形の影響は，格子間隔を小さくす ればかなりの精度で予測できると考えられるか。

(河井 宏充)

回答 数值予報の精度は, 他の数值計算と同様, 初期 条件，境界条件，そして計算手法そのものの精度に依 存しています。そして, 現象によって初期条件に非常 に敏感に反応する現象もあれば，地形という境界条件 に強く依存する気象現象もあります。数値予報の初期 値を与える最も重要な観測は, ゾンデによる高層観測 ですが，これは約 $300 \mathrm{~km}$ に1個の割合しかなく，小さな 気象現象を予報するには少なすぎます。その意味では 格子間隔を単純に小さくすることに疑問がない訳では ありません。しかし, 地上付近の風の場合, 大きなス
ケールの場を与えた時に地形（境界条件）によって風 がどう変型されるか，という点が重要になってきます。 そのため, 大きなスケールの気圧場さえうまく予想 できていれば，地形の影響を強く受けた風の予報は十 分可能であるという考えもあります。私たちの経験か らいえば，少なくとも地上風の予想に関しては，格子 間隔を小さくするだけで（それに応じてモデルの地形 も細かくするので），予報精度は非常に良くなると言 えます。現在気象庁でルーチンに使っているモデル（J SM) で，もっとも分解能の細かいものの格子間隔は 40 $\mathrm{km}$ ですが，その予報精度は複雑な地形をもつ山岳部で 悪くなります。しかし，分解能を単純に10kmにしたモ デル（初期值も同じ）でも，地形に応じた風系がうま く予想されるようになります。私の個人的な印象で言 えば，少なくとも5 $\mathrm{km}$ ぐらいまでは精度の向上が望める ように思います。（*気象庁 観測部）

質問 強風に限定して扱ったり，または，今後12時間 内の最大値という形の予測であれば，はるかに精度も 向上し，予測をより有効に使えるのではないか。

（神田順）

回答 ご指摘の通りだと思います。今回示した精度の 検証は，ある時刻に対する観測と予測を比較したもの ですが，一部の気象官署では独自に時間的に幅を持た せての最大風速の検証を行っており，予測精度がかな り上がることを指摘しています。

風に限りませんが，予報結果を利用する場合，有効 であるかないかというのは利用する側がどの様な使い 方をするかによって大きく変るかと思います。時間と 空間を特定した予報を望むユーザーと，ある程度幅を 持たせた時空間での情報を欲する人とでは, 要求する 精度にも自ずと違いが生じます。気象庁では，今まで 文章による天気予報しか発表してきませんでしたが， 数值予報の格子点デー夕も部外（自治体や民間天気予 報会社, 航空会社など）に提供していこうという動き があります。数值予報データが自由に使えるようにな れば，ユーザーが目的に応じて加工し利用することで， 真に有効な利用に繫がると考えます。 